\title{
Communicative-Functional Potential of Incentive Modality in Psycholinguistic Dimension
}

\section{Комунікативно-функційний потенціал спонукальної модальності в психолінгвістичній проєкції}

Vasyl Shynkaruk

DSc. in Philology, Professor
Василь Шинкарук

доктор філологічних наук, професор

E-mail: vashyn2010@ukr.net https://orcid.org/0000-0001-8589-4995

ResearcherID: X-7699-2018

Svitlana Kharchenko

DSc. in Philology, Associate Professor
Світлана Харченко доктор філологічних наук, доцент

E-mail: lucynka@ukr.net https://orcid.org/0000-0001-9336-1259

National University of Life and Environmental Sciences of Ukraine

15, Heroiv Oborony Str., Kyiv, Ukraine, 03041
Наиіональний університет біоресурсів і природокористування України вул. Героїв Оборони, 15, Київ, Україна, 03041

Original manuscript received October 30, 2019

Revised manuscript accepted October 15, 2020

\section{ABSTRACT}

The objective is to substantiate the psycholinguistic parameters of the category of incentive modality that has a direct connection with a number of mental phenomena and the speaker and the addressee, and describe the psycholinguistic model of the act of volition in combination with the study of the mechanisms and processes 
of perception, interpretation and speech generation governing the functioning of a language unit in a certain psycholingual dimension and its interpretation by the addressee.

Materials \& Methods. To achieve the stated goal, the descriptive method with its inherent means of external and internal interpretations was used as the main one; the pragmatic method involving the methodology of speech act analysis was also applied to determine the components of the psycholinguistic model of an incentive act and distinguish the types of incentive utterances; classification method - for inventory and systematization of indirectly incentive utterances, contextual-interpretive method - for establishing the transposition of non-incentive utterances into incentive ones in speech activity; intent analysis is involved in the study of indirectly incentive utterances that the addressee interprets as incentive ones in a speech situation.

Results. The analysis of the inextricable interconnection of psychological, mental and linguistic processes made it possible to determine the psycholinguistic parameters of the category of incentive modality, in which the content plan (intentional needs of the speaker: orders, wishes, warnings, etc.) and the plan of linguistic representation are clearly explicated. Based on this approach the incentive is interpreted both as a psycholinguistic concept and a linguistic universal category; the components of the linguistic model and the functional structure of the incentive act are defined. The bidirection of the act of volition is emphasized.

Conclusions. It is established that the focus on the positive result of the incentive foresees the obligatory accounting of distinguished or assumed background knowledge, the usage of the single sign system for encoding and decoding information, conventions, communicative situations, etc. The incentive explicates the volitional impulse, the indication to the addressee of the incentive action.

Key words: incentive, psycholinguistic model, motive, need, communicative situation, vocative utterance, incentive modality.

\section{Introduction}

The studies of grammatical phenomena in the psycholingual aspect do not only lose their topicality but also manifest new facets. Investigating the role of a language in the cognitive activity and mindset of a person, the correlation of language semantics and knowledge about the world enables to describe a language as the reflection of the conceptual picture of the world, the mentality of the nation, etc. In addition, modern linguistics is characterized by the immersion into the internal structure of the language system in combination with the study of the patterns of language units' functioning in a certain communicative-pragmatic dimension, where the speaker and the listener 
interact in the process of object-practical and theoretical cognitive activity. The interaction does not occur for its own sake. Ultimately, the main function of the speech activity is not the information exchange, but the influence of one person on another one.

One of the verbalization means of such interaction at the syntactic level is the incentive (in the terminology of speech acts - directive speech acts, or directives) sentences, the basic differential semantic feature of which is the ability to express various types of human volition: order, demand, direct address, wish, request, advice, permission, etc. (Vykhovanets, 1993; Shynkaruk, 2002; Kharchenko, 2015 et al.).

The incentive is an important aspect of the theory of speech acts, the founder of which is considered to be J. Austin. He proposed to distinguish three components in the «act of speech»: locution (or the locutionary act), illocution (or the illocutionary act), perlocution (or the perlocutionary act) (Ostin, 1986: 82-83). J. Austin examines the role of utterances (locutionary acts) in interpersonal communication from the point of view of the intentions of the speakers during communication (the illocutionary power of their utterances) and the influence that they exert on the recipients (the perlocutionary effect of the utterances). The illocutionary acts the scientist divided into five categories: verdictives, expositives, exercitives, behabitives and commissives. J. Searle (1986) substantiated the distinction between perfomative acts and illocutionary acts and proposed his own classification of illocutionary acts, which was recognized by the world scientific community: assertives, directives, commissives, expressives and declarations. These are the directives that express the request, order, command, demand, etc., i. e. they contain the seme of «incentive». However, in the Ukrainian linguistic tradition, the theory of speech acts did not receive distribution, although there are some studies, on the taxonomy of speech acts in particular. But in the paradigm of communicative types of sentences there are four grammemes - narrative, interrogative, incentive, optative (desiderative) sentences. As an intermediate, hybrid type of sentences, performative sentences are distinguished by the criterion of the «communicative goal» that absorb the signs of narrative and incentive sentences.

The incentive utterances in the Ukrainian scientific discourse have become the object of research as one of the communicative types of utterances (Vykhovanets, 1993; Dudyk, 1971 et al.). The incentive sentences in semantic and communicative-functional manifestations were 
studied by S. Kharchenko (2015), V. Shynkaruk (2002), in the aspect of pragmalinguistic theory - by O. Narushevych-Vasylieva (2002), O. Daskaliuk (2006) et al.

In foreign linguistics, incentive (imperative) utterances have also become the subject of linguistic and psycholinguistic research. In particular, the incentive (imperative) utterances of the English language, their structure and interpretation in speech activity have been monographically described (Han, 2000). In addition, the meanings and illocutionary force of imperative utterances (Condoravdi \& Lauer, 2012) have been interpreted, the mechanisms of acquisition in speech implementation under the influence of external factors by directives as varieties of imperative utterance of non-directive meaning are considered (Holvoet, 2020), the psychological correlates of imperative speech through pronouns (Markowitz \& Slovic, 2020) and the role of connectives in complex according to the structure incentive utterances (Keshet \& Medeiros, 2019) have been highlighted. Polish linguists, for example, have studied incentive (imperative) utterances as an act of will, noting that in atypical situations a requirement or a prescription is not always expressed imperatively (Brożek \& Jadacki, 2012) or through the prism of appellation (Zaucha, 2016).

Despite the increased interest in the incentive utterances, the consideration of these speech units in connection with psychomental human activity is still not determined, since for the establishment of informational referential content of the incentive utterance the role of subjective-pragmatic factors associated with the speakers' personalities, in particular with their communicative objection (intention), motivation, as well as with the expected result (feedback) should be taken into account. Out of the field of scientists' vision is the situational perception of non-incentive speech units as incentive ones.

The aim of the proposed research is to substantiate the psycholinguistic parameters of the category of incentive modality that has a direct connection with a number of mental phenomena and with the speaker and the addressee, and describe through the mechanisms and the processes of perception, interpretation and speech production the psycholinguistic model of an act of volition in combination with the study of the tendency of a language unit's functioning (on the example of vocative statements) in a certain psycholingual dimension and its interpretation by the addressee. 


\section{Methods and Methodologies of Investigation}

To achieve the stated goal, the descriptive method with its inherent means of external and internal interpretations is used as the main one, the pragmatic method involving the methodology of speech act analysis (to determine the components of the linguistic model and the functional structure of an act of volition and the establishment of dependencies between them, as well as to differentiate the types of incentive sentences) is also used. The classification method is applicable for inventorying and systematizing indirectly stimulating utterances, contextual-interpretive - for establishing the transposition of nonincentive utterances into incentive ones in speech activity.

Intent analysis, used in psycholinguistic research as a method of identifying and objectifying hidden forms of verbal influences and intentions of the communicator, is involved in the study of indirectly stimulating statements, which in a particular speech situation the addressee can interpret as incentive, taking as the basis not the verbal content of the statement, but implicit or disguised meaning. Conducting an intent analysis contains procedures such as identifying intentions, due to the fact that the speech behaviour of a person in society is always intentionally directed, and their expert assessment.

Besides, in order to achieve the above-mentioned aim, we have chosen methodological principles about the inseparable connection between language and mindset, manifested at all stages of human development - from ancient times till nowadays. This relationship is reflected in the two main functions of a language - communicative and cognitive, which constitute the unity.

The methodology (procedure) of our research is specified in the following operations:

(1) clarification of the scope of the concept «category of incentive modality» through the prism of psycholinguistics;

(2) generalization of the factors of speech activity that generate incentive semantics, explicated in specialized and non-specialized structural schemes;

(3) elucidation of the psychological factors that form the incentive act, determine its structure, and also generate, organize the incentive utterance and affect its perception; 
(4) identification of the communicative conditions for the interpretation of vocatives as incentive utterances;

(5) insertion of the functions of vocative incentive utterances in speech activity.

\section{Results and Discussion}

Effective targeted speech influence can only be effective when it is «based on a clear understanding of the psychological mechanisms of influence...» (Leontiev, 1971: 10).

Therefore, the study of the category of incentive modality is impossible without taking into account the psychological characteristics of the individual, because psychology sheds bright light on the "physiology» of these processes and their occurrence.

Incentive utterances, while creating themselves according to laws of a language, most fully display their categorical meaning in live implementation - speech activity, which we characterize as dynamic one in the speech environment, is modified under the influence of external and internal factors, such as streamlining, hierarchization of social life. Only in speech the generic meaning of the category of the incentive modality is specified by having undergone various modifications.

The category of the incentive modality is the functional-semantic category, covering emotional-volitional relations between communicants, determined by their communicative attitudes, needs of motivation's realization in speech, which [realization] in its specific manifestations is due to personal, social and situational factors.

The generation and structuring of incentive utterances in speech activity occurs on the structural inner language basis of the incentive determined by the means of different language levels: specialized morphological and syntactic means (imperative mood of the verb, incentive constructions) and unspecialized means (verb forms in other moods, disincentive constructions) whose role in the expression of the incentive is various, differentiated (Shynkaruk, 2002; Kharchenko, 2015).

Semantics of the incentive utterances is formed by such aspects of the communicative activity as:

- volition and purposefulness as a differential sign of the selection of one of the communicative types of the sentence - incentive; 
- expression of the irreal value, contrasted with the forms of the real meaning and other subtypes of the irreal meaning;

- personal - the speaker's attitude to the content of the message;

- social - relationship between the communicants: such as a senior - a junior, a leader - a subordinate, a friend - a stranger, parents - children, official relations - informal relations, etc.;

- psychological affinity between communicants (close / far);

- situationality - the impact of a specific communicative situation on the act of volition (incentive);

- obligatory addressing.

The psycholinguistic model of the act of volition (incentive) contains all the above-mentioned aspects.

The implementation of an act of incentive in speech activity obligatory provides the presence of at least two participants: the initiator of the incentive and the recipient / the doer of the action. The act of incentive occurs in communication, it is a necessary and the most important socio-psychological aspect of any activity.

Using the incentive utterances, expressed by specialized means, the communicants tell openly about their intention to influence someone or something. But the actualization of non-specialized means of expressing an incentive value in speech activity depends on a number of factors, in particular, on the participants of a communicative (narrower - incentive) act, because

«each linguistic personality is unique, has his / her own thesaurus, patterns of speech behaviour, system of communicative values» (Yasakova, Kharchenko \& Shynkaruk, 2019: 204),

which actualize, under the influence of external factors, specific, specialized or non-specialized, means of expressing incentive. The use of non-specialized incentive utterances is aimed at avoiding communicative errors, conflicts, aggressiveness that arise, according to scientists, because communicants of different age, social and communicative status, physical and psychological state, intellectual, mental and cultural levels participate in the communicative process (Bosco \& Gabbatore, 2017).

Communication, like any other activity, has its own obligatory characteristics. According to A. Leontiev, this is, firstly, intentionality (the presence of a specific goal, independent or subordinate to other tasks, the presence of a specific motive), secondly, its productiveness 
is the degree of coincidence of the achieved result with a specific goal; thirdly, the norm, which is expressed primarily in the fact of mandatory social control over the flow and effectiveness of an act of communication (Leontiev, 1971: 23). Psychologists, in particular L. Kalmykova, attribute processuality, presence of the subject and the object of speech, motive (need), intention, purpose, content and language means to obligatory components of communication (a speech event or a communicative situation) (Kalmykova, 2007).

Volition (incentive) as a kind of mental speech activity, as a set of certain actions is due to what is motivated, like everything else in the objective world. The basis of the incentive is the dialectical contradiction, which, moreover, is the impetus for any mental activity the contradiction between what matters objectively for a person's vital activity, and a person interprets it as something that has a subjective meaning, on the one hand, and an available activity, on the other hand. That is why among the prerequisites of an act of volition (incentive) as one of the components of speech activity, there are contradictions arising between what should be the behaviour (actions, deeds, etc.) of another participant / other participants that takes part / take part in interaction from the point view of the communicant, and the way it is. The speaker, as the creator of the communicative-pragmatic field, organizes it from the standpoint of egocentrism (Yasakova, Kharchenko \& Shynkaruk, 2019: 204).

However, motivation is not an impulse that becomes the cause of the volitional process, it is not the primary source of activity, but a complex regulator of human activity that supports, changes, blocks the mental behaviour of communicants during the whole volitional process. The motive determines the genesis of speech and the structuring of the utterance. Motivation determines

«firstly, to speak or not to speak, secondly, if we speak, what form the statements will have (statement, question, order, etc.), thirdly, if a form is chosen, then what means to use to express it in a sentence, highlight it with logical stress》 (Leontiev, 1971: 133).

Definitely, motivation is based on motives. The motive is the inner state of personalities, which determines their actions; the motive is what leads to the activity and is associated with the satisfaction of needs. The basis of the motive is the needs and interests. In general, 
needs turn out to be a necessity for something; an appropriate form of an activity is needed to satisfy them. During the incentive, which is the act of volition, the communicators need, want, desire the communicants to change or adjust their activity according to their [communicants'] instruction. The need is the first impetus, the source of an activity, its main driving force; it acts objectively, in the sphere of the subjective it turns into an interest, i. e., it becomes a conscious need (Leontiev, 1971: 23). A significant role is played by emotions as a mandatory, obligatory component of functioning and producing the incentive act. Actually, the valuable evaluative attitude of interlocutors to the goal, tasks and results of their speech activities and the activities of others is based on emotions that force a person to act under certain (un)favorable conditions. The emotional sphere in speech has its own representatives specific lingual markers (Argaman, 2010).

The communicator on the basis of the specific motive, conditioned by the conscious need or the valuable evaluative attitude, sets the goal: to influence the communicants in such a way as to change, correct, coordinate their behaviour in accordance with their desires. The incentive act as

«a single act of activity is the unity of all its three components: it starts with the motive and the plan, and ends with the result, the achievement of the originally intended goal; between them there is a dynamic system of specific actions and operations aimed at this achievement» (Kalmykova, 2007: 163).

An act of volition is not unilateral, but bidirectional. It means that the person who receives and interprets the impulse of incentive also makes volitional efforts aimed at achieving a certain result (with a positive or a negative sign). In the mind, regarding the objective content of the decision, it is possible to single out the worries "I have to ...», «I want ...», «I can ...», «I am interested in ...», which point to another feature of will. People in this case worry about what they need, want / do not want, can / cannot do to implement what is required. And it is due to the will of the communicant, which was influenced, the incentive has some kind of result.

To perform the act of incentive, therefore, it is necessary to have two participants; the one who produces the incentives (volitions) - the communicator, and the one to whom the incentives are directed - the 
object of the incentive (when the direct incentive is realized), or the speaker and the listener who perform the function of an informant for a potential performer / performers of an incentive action, in the context of an indirect implementation of the incentive. The communicators, guided by the motives, set a goal that has the emotional-evaluative characteristics and on the achievement of which their speech actions are directed. In order to implement certain tasks the communicator directs his speech actions in such a way that through the impact on the motivational sphere (the motive that under given conditions is most closely linked to the prospect of achieving the result is activated) and through changing the emotional-evaluative characteristics of the objective reality of the communicant, he [the communicant] intensified his activities as it is required by the speaker. The communicator and the communicant do not act in isolation, but in a certain social and natural environment.

To achieve a positive pragmatic effect of the incentive the speaker uses various channels, methods of influencing the interlocutor / interlocutors. In psycholinguistics three channels of influence are defined: messages, compulsions and convictions. Their distinction has a conditional character: they are all interconnected and to some extent present in the process of speech influence.

At first glance, the message is like the most common, emotionally neutral form of presentation, transmission of thought. However, the category of narrative modality, as well as the category of incentive modality, is rich in semantic and expressive shades, including some joint, interpenetrating shades. Therefore, the boundaries between them can be erased. In speech activity, depending on the motive as a psychological parameter that determines the verbal and non-verbal behaviour of a person, and the communicative situation, the phrase Pryihav likar Zubytskyi [Doctor Zubytskyi has arrived], pronounced neutrally from the emotional side, with a narrative intonation, one person will perceive as an ordinary message, while another being interested or, on the contrary, not interested in a meeting with doctor Zubytskyi, will perceive this message as the indirect incentive to an action. The activation of transpositional processes in grammatical and semanticsyntactic meanings occurs primarily in oral speech. Let us consider this on an example of vocative utterances (or, in another terminology, vocative, vocative communicant), which under certain communicative 
conditions acquire incentive meaning and belong to non-specialized speech means of expressing incentive.

The content of vocatives in a «hidden» and not dissected way expresses a certain thought-feeling that accompanies a direct address to a person and is implicitly present in a communicative situation (in a spoken language) or from a context (in the written speech), outside of which the functioning of the direct-address sentences that constitute to the fullest extent expressive constructions is inconceivable (Dudyk, 1971: 38). K. Shulzhuk pointed out that the specific feature of this type of sentences is that

«not formally grammatical indicators are determinable in them, but internal, semantic meanings, which, as a rule, do not exist in a particular context, but are thought out, such which are logically stipulated by the specifics of the situation, the content of the statement» (Shulzhuk, 1968: 130).

In the basis of the vocative utterances of incentive modality there is a direct address. A grammatically designed direct address not only names the addressee of the speech, but also conveys informationally complete statements, implicitly condenses the wealth of semantic shades that the addressee «reads» from intonation and communicative situation. Such constructions are maximally compacted semanticsyntactic structures.

The distinction between actually vocative and incentive vocative utterances is based on the communicative (contextual) criterion: if a vocative utterance precedes another utterance of any modality, then such a sentence is actually vocative; vocative statements used in isolation or after another sentence of a narrative or interrogative modality are qualified as the sentences of incentive modality (Kharchenko, 2015: 100). For example: (1) - Serzhant Kolomiiets! - poklykav Sagaida polkovogo zviazkivtsia, yakogo znav shche $z$ Dintsia $i$ yakyi zaraz vykonuvav $u$ niogo oboviazky rozvodiashchogo. - Odvedy tsiogo ... «variaga» na post (Honchar, 1987) [- Sergeant Kolomiiets! - called out Sagaida to the regimental signalman, whom he had known since the Donets and who now performed his duties as a guard commander. - Take this ... «Varangian» to the post (Honchar, 1987)]; - Bozhe velykyi! Bozhe myloserdnyi! - kazhe, prostiagshy ruky do obraza. - Polozhyv yesy yomu moiu naidorozhchu dumku, pomozhy zh yomu i dokazaty 
siu spravu! (Kulish, 1990) [- Great God! Merciful God! - he says, holding out his hands to the icon. "If you give him my dearest opinion, help him to prove this matter!» (Kulish, 1990)] - actually vocative utterances; (2) - Tovaryshu hvardii molodshyi leitenant! - poklykaly Chernysha des znyzu, z-pid nasypu. Obernuvshys, vin pobachyv biitsia svoho vzvodu Gaia, vysokoho, sumyrnoho yunaka (Honchar, 1987) [-Comrade of Guard Junior Lieutenant! - Chernysh was_called from somewhere below, from under the embankment. Turning around, he saw the fighter of his platoon Gai, a tall, quiet youth (Honchar, 1987)] the vocative incentive utterance. Both utterances (1 and 2) outside the communicative situation will be decoded by the addressee as direct address. The communicative situation «prompts», concretizes, clarifies the content of what was said. In the end, communication is focused not only on the direct meaning of the statement, but on its interpretation, because we are not exchanging words and their meanings, but thoughts, using language only as means of speech activity. Definitely, opinion is primary and initial in the process of communication.

The expression of a certain variant incentive value by vocative utterances occurs not through its direct sense, but through the rethinking of the direct address, which in the context of a specific communicative situation is decoded by the addressee based on his / her linguistic knowledge and interpretation of the utterance, taking into account conventions (social customs, cultural traditions, accepted patterns of speech behaviour in a specific communicative situation). The listener determines the content of the utterance on the basis of his / her background knowledge, and accordingly his / her ability to navigate through events and mentally foresee their further development.

The main function of the vocative utterances is phatic, i. e. establishing communicative contact through nomination of the addressee of speech. Since the direct-address utterances have condensed various expressive and semantic shades, it is quite natural that these utterances, under certain communicative conditions, fulfill phatic-incentive function, which is a combination of the actual phatic (contact-establishing) and incentive, in particular its semantic variants - requirements, orders, commands. For example: (3) Dmytro pryishov pizno. $<\ldots>$ Vid rannoi vesny nochuvav pid oborogom niby tomu, shcho $v$ khati zadukha. - Dmytre, agov, Dmytre! - tykho pozvala Ilchykha. Chula, yak neokhoche ziskochyv $\boldsymbol{z}$ drabyny (Vilde, 2010) [Dmytro arrived late. 
$<\ldots>$ From early spring he spent the night under the threshold as if there was stuffiness in the house. - Dmytro, hey Dmytro! - quietly called Ilchykha. She heard how reluctantly he jumped down the stairs (Vilde, 2010)]; (4) ...Mozhe, maty v kukhni? Galyna boitsia poklykaty, vona boitsia, shcho ne pochuie vidpovidi. Yii malenke sertse ladne vyskochyty z hrudei. - Galyno! Galiu! - Divchyna zdrygaietsia. Vona bizhyt na batkiv golos, ale nogy $v$ nei staly znenatska nemov chuzhi (Donchenko, 1987) [.. Maybe the mother is in the kitchen? Galyna is afraid to call, she is afraid that she will not hear the answer. Her little heart is ready to jump out of her chest. - Galyna! Galia! - The girl winces. She runs to her father's voice, but her legs have suddenly given upon her (Donchenko, 1987)]. In the provided examples, we trace the speaker's intention not only to establish contact with the specific, familiar person, but also implicitly expressed desires, the requirement for the addressee to come to the house (3) or run to her father (4), etc.

The vocative utterances perform the phatic-incentive function even when the communicants are not personally acquainted, however one of them needs a change in reality. For example: (5) - Sprobuimo! - skazav Burunda i, vkhopyvshy rukoiu za grudy Maksyma, vytiag yogo pered sebe. Bilia nogo stav Tugar Vovk i pochav makhaty biloiu khustkoiu. - Tukholtsi! - zakrychav vin, zvertaiuchys do berega. Tykho stalo dovkola (Franko, 2006) [- Let's try! - said Burunda, grabbing his hand by the chest of Maxim, and pulled him in front of him. Tugar Vovk stood near him and began to wave a white handkerchief. - Tukholtsi! - he cried, turning to the shore. It became quiet around them (Franko, 2006)]; (6) Zzadu poklykano: - Tovaryshu! Tovaryshu! (Pidmogylnyi, 1989) [It was called from behind: - Comrade! Comrade! (Pidmogylnyi, 1989)]; (7) Zupynyvs [Makar] bilia stovpa, shcho kolys na nomu tripotilo dyvne ogoloshennia. Otut yogo i pobachyla Zina. - Sashka! - vyguknula. Makar ozyrnuvsia. Zina vzhe bigla do nogo, ruky prostiagala, rydala rydma (Liuko Dashvar) [Makar] stopped at the pillar when once a strange announcement fluttered on it. Then Zina saw him. - Sashka! - she exclaimed. Makar looked around. Zina was already running towards him, holding out her hands, sobbing (Dashvar, 2011)]. The speaker, calling the person (people) who should become the performer of the incentive action, establishes the contact and at the same time requires something: silence and to be heard (5) and from the person to turn around, stop and wait $(6,7)$. 
The vocative utterances can also be used with the phatic-incentive aim in situations where the communicants are familiar with one another, and their relationships are regulated by their social status, communicative roles, age, and the like. In this case, both the communicant and the communicator are internally ready to implement the incentive, just as the speaker requires, for example: (8) U pershu myt Rikhter stoiav ni $v$ tykh, ni $v$ sykh, todi obviv pogliadom natovp, distav z kobury valter $i$ pidtiuptsem pobig do gurtu politseiskykh. - Manzhus! - zakrychav Rikhter. Manzhus vytiagsia pered nym (Zemliak, 1981) [In the first instant, Richter found himself in a tough position, then he looked around the crowd, pulled Walther out of his holster, and jogged to a group of policemen. - Manzhus! Richter shouted. Manzhus pulled himself in front of him (Zemliak, 1981)]; (9) - Prosiu pokorno za stil! - zaprokhuvala Ogyrykha. - Lizochko, ty zh taky khaziaika... I de ta Zinka vasha, khoch by dytynu $v$ molodytsi vziala. Zinko! - pogukala v kukhniu. Ta vybigla i vziala dytynu (Holovko, 2017) [- Sit down obediently for dinner! - invited Ogyrykha. - Lizochka, you're the mistress ... And where is your Zinka, if only she took a child from a young maid. Zinka! - she called to the kitchen. She ran out and took the baby (Holovko, 2017)].

The vocative utterances of incentive modality are also used to restore contact, establish the communication channel that has just been broken. In such a situation, the performance of an incentive action (for example, the cognitive situations «Return» (10), «Speak» (11, 13), «Do not go» (12), «Answer» (10), etc.) completely depends on the addressee of the incentive, his / her desires, moods. Наприклад: (10) Oleksii (v storonu): Skhamenulas! Nekhai pokortyt! (Ide dali). Uliana: Oleksiiu-bo! (Kvitka-Osnovianenko, 1978) [Olexii (to the side): Came to her senses! Let her want it! (Goes further). Uliana: Oleksii! (Kvitka-Osnovianenko, 1978)]; (11) Ryta. Korniiu. Govory: prodaiesh? (Kornii glyboko zitkhaie. Movchyt. Tykho robyt rukoiu dytyni zabavku) Ryta. Korniiu!.. (Vynnychenko, 1990) [Ryta. Kornii. Tell: do you sell it? (Kornii takes a deep breath. He is silent. He quietly makes with his hand a toy to a child) Ryta. Kornii!.. (Vynnychenko, 1990)]; (12) Vin kholodno vidkhylyv druzhynu, promymryv shchos nevyrazne $i$ pokhaptsem, nemov tikaiuchy od peresliduvacha, pishov do dverei. - Andriiu! - z odchaiem u golosi guknula Sima (Slisarenko, 1990) [He coldly rejected his wife, muttered something slurred, and hurriedly, as 
if running away from his pursuer, went to the door. - Andrii! - Sima cried out with despair in her voice (Slisarenko, 1990)]; (13) - Ta dobre, sontse. Kavy zavaryty? Za yakyi chas budete? Gostei bagato?.. Marta ne vidpovidala. Makar skryvyvsia z prykristiu: mozhe, vona shche $i$ glukha? - Marto... - Ne treba kavy, liubyi, - prolopotila. - Zustrich duzhe vazhlyva $i$ duzhe... pryvatna (Liuko Dashvar) [- Come on, sunshine. Shall I brew some coffee? When do we expect you? Are there many guests? .. Marta did not answer. Makar grimaced in frustration: was she also deaf? - Marta ... - No coffee, honey, - she said. - The meeting is very important and very... private (Dashvar, 2011)].

However, in everyday typical communicative situations vocative utterances with transposed semantic-syntactic meaning are not only used to call for someone, ask, demand to respond somehow to a call, etc. as in (5-13), but also in order to warn, prohibit, caution: (14) Vykruchuvav ruky, tiagnuvsia do gorlianky, povalyv na pidlogu, ta slovamy dila ne zipsuvav. - Ty - moia... Ty moia zhinka! Moia! - Sasho, Sasho... - V ochakh zhakh. - Ubiu! - Zamakhnuvsia [He twisted her arms, reached for her throat, knocked her to the floor, but he did not spoil the matter with words. - You are my ... You are my woman! My! - Sasha, Sasha ... - There was horror in the eyes. - I'll kill you! - He lifted his arms against her (Dashvar, 2011)]; (15) - U tebe [Olenko], napevno, khorosha mama. - I vrodlyva, - vidpovidaie divchynka. - A tata nemaie, tilky didus. Didus, bachyte, vzhe starenkyi, vin ne mozhe nosyty mene na plechakh. Odnoho razu mene nis diadko Lonia. Ale diadko Lonia vzhe ne prykhodyt - vin u kosmos poletiv, tak mama skazala. A koly mama vyduzhaie, $v$ nas ishche sto takykh diadkiv ziavytsia, - tak babusia skazala! - Olenko! - dokirlyvo khytaie golovoiu didus (Rozdobudko, 2011) [- You [Olenka] must have a good mom. - And beautiful, - the girl replies. - But there is no dad, only grandfather. Grandfather, you see, is already old, he cannot carry me on his shoulders. Once uncle Lonia carried me. But no longer does uncle Lonia come - he flew into space, as my mother said. And when mom gets well, we'll have another hundred of these men appear, - grandmother told like this! - Olena! grandpa shakes his head reproachfully (Rozdobudko, 2011)].

The

«correct reading» of implicit in an utterance is possible under condition of having the same speech encoding and decoding 
parameters, because speech "encodes the perceived information» (Tillman \& Louwerse, 2018: 159).

Decoding of what was heard is a complex, integral psychological process that begins with the search for the general meaning of the statement, where the predictions and attitudes that arise in the speech consciousness of the addressee, as well as non-verbal elements of speech and reference play a great role.

Emotionally expressive colouring of the vocative utterances of incentive modality in the speech act can be enhanced, emphasized. This happens when the direct address is repeated several times (two or more): either simultaneously, sequentially or at a certain interval. For example: (16) Kriazh. Khodim, Omeliane! Do svogo druga davnogo ta ne pity. Oliu! Oliu! (Uviishla Olha) (Zarudnyi, 1979) [Ridge. Let's go, Omelian! How can't you come to your old friend. Olia! Olia! (Olga came in) (Zarudnyi, 1979)]; (17) Ale Zhorzhetta, niby ne chuiuchy, z vyklykom provadyla svoiei: - Tozh yak vy mogly mene zapamiataty?! Zate vy buly... yak kinozirka! Taka krasyva zolotovolosa pryntsesa! Ya, do rechi, bula u vas zakokhana, i navit prydumala vam imia kazkove: Vio-Vio-Vioreli... Ne serdtes, ale ya vas tak ... z liuboviu nazyvala, doky.. doky ne... - Zh-zh-zheto! - zasterezhlyvo, proshypila Milia, odnak Vioreliia Viorelivna, zaskochena nespodivanym osvidchenniam, ne zvernula na te uvahy (G. Tarasiuk); ... i, trokhy, strusyvshy kaminnia z dushi, idu dodomu. - Hanno, Hanno, - khtos gukaie mene. Rozzyraius (Tarasiuk, 2006) [But Zhorzhetta, as if not hearing, challenged her: - So how could you remember me?! But you were ... like a movie star! Such a beautiful golden-haired princess! By the way, I was in love with you, and even came up with a fabulous name for you: VioVio-Vioreli ... Don't be angry, but I called you like that ... with love, till .. until ... - Zh-zh-zheto! - warningly, hissed Milia, but Vioreliia Viorelivna, captured by unexpected recognition, did not pay attention to it (Tarasiuk, 2006); ... and, shaking off the stones from my soul a little bit, I go home. - Anna, Anna, - someone shouted to me. I am looking around (Tarasiuk, 2006)]. The speaker uses repetition of the direct address with a certain time interval when the addressee of the incentive did not respond properly to the impulse of the addressee's volition for subjective reasons (for example, due to ignoring the speaker's desires, aspirations) or due to circumstances beyond his / her control. In this 
case, each subsequent vocative utterance is pronounced with greater expression, acquiring maximum emotional stress in the latter.

\section{Conclusions}

In the act of volition psychological, mental and language processes are inseparably connected. The analysis of this connection allowed interpreting the incentive both as a psycholinguistic concept and as a linguistic universal category, determining the components of the linguistic model and the functional structure of the incentive act.

Each act of volition reflects emotional-volitional relations between the communicants, caused by personal (psychological), social and situational factors.

The focus on the positive result of the incentive provides the obligatory accounting of known or assumed background knowledge, social and communicative status of interlocutors, communicative situations, etc. The incentive explicates a volitional impulse, an expression of a certain incentive for an action, an indication of an incentive action to the addressee.

According to communicative intentions, dismembering the speech stream, taking into account the conditions for the explication of mental processes during the generation and perception of speech, the speaker uses specifically compacted semantic-syntactic structures to which the vocative utterances of incentive modality belong. They are interpreted as unspecialized means of expressing incentive meaning.

Correction, clarification of the semantic organization of a statement is determined by (1) the need to comprehend and solve communicative tasks according to the goal that the speaker sets himself / herself; (2) the situation in which the speech act is implemented; (3) circumstances that became prerequisites for the emergence of a specific communicative situation; (4) conventions and background knowledge. The above mentioned information may be of special scientific interest in upcoming papers.

\section{References}

Argaman, O. (2010). Linguistic markers and emotional intensity. Journal of Psycholinguistic Research, 39(2), 89-99. https://doi.org/10.1007/s10936-009-9127-1 
Bosco, F., \& Gabbatore, I. (2017). Theory of mind in recognizing and recovering communicative failures. Applied Psycholinguistics, 38(1), 57-88. https://doi. org/10.1017/S0142716416000047

Brożek, A. \& Jadacki, J. (2012) O rozumowaniach imperatywnych. Acta universitatis Lodziensis, 25, 133-149.

Condoravdi, C., \& Lauer, S. (2012). Imperatives: Meaning and illocutionary force. Empirical issues in Syntax and Semantics, 9, 37-58.

Daskaliuk, O.L. (2006) Semantyko-hramatychna kharakterystyka imperatyva suchasnoi ukrainskoi movy [Semantic and Grammatical Characteristics of Imperative in Modern Ukrainian]. Candidate's thesis. Chernivtsi [in Ukrainian].

Dudyk, P.S. (1971). Sponukalni rechennia i slova-rechennia [Incentive sentences and words-sentences]. Ukrainska mova i literatra $v$ shkoli - The Ukrainian Language and Literature at School, 9, 30-35 [in Ukrainian].

Han, C.-H. (2000). The Structure and Interpretation of Imperatives: Mood and Force in Universal Grammar. New York: Garland.

Holvoet, A. (2020) Sources and pathways for non-directive imperatives. Linguistics, 58(2), 333-362. https://doi.org/10.1515/ling-2020-0043

Kalmykova, L.O. (2007). Movlennieva diialnist yak skladova predmeta psykholingvistyky [Speech activity as the subject's component of psycholinguistics]. Humanitarnyi visnyk Pereiaslav-Khmelnytskoho derzhavnoho pedahohichnoho universytetu imeni H. Skovorody - Humanitarian Herald of Pereiaslav-Khmelnystkyi Hryhorii Skovoroda State Pedagogical University, 160164 [in Ukrainian].

Keshet, E., \& Medeiros, D.J. (2019). Imperatives under coordination. Natural Language and Linguistic Theory, 37(3), 869-914. https://doi.org/10.1007/s11049018-9427-y

Kharchenko, S. (2015). Zasoby vyrazhennia sponukannia v ukrainskii literaturnii movi: semantyko-syntaksychnyi i komunikatyvnyi aspekty [Means of expressing incentive in the Ukrainian literary language: semantic-syntactic and communicative aspects]. Kyiv: Milenium [in Ukrainian].

Leontiev, A.N. (1971). Potrebnosti, motivy $i$ emotsii [Needs, motives, emotions]. Moscow: Izdatelstvo Moskovskogo universiteta [in Russian].

Markowitz, D.M., \& Slovic, P. (2020) Communicating Imperatives Requires Psychological Closeness But Creates Psychological Distance. Journal of Language and Social Psychology, 39(5-6), 598-625. https://doi. org/10.1177/0261927X20902816

Narushevych-Vasylieva, O.V. (2002) Katehoriia sponukalnosti u prahmastylistychnomu aspekti [Category of Incentive Modality: Pragma-Stylistic Aspect]. Candidate's thesis. Odesa [in Ukrainian].

Ostin, Dzh. (1986). Slovo kak deistviie [How to do things with words]. Novoie $v$ zarubezhnoi lingvistike - New in World Linguistics, 17, 22-131 [in Russian].

Serl, Dzh. R. (1986). Klassifikatsiia illokutivnykh aktov [Classification of illocutionary acts]. Novoie $v$ zarubezhnoi lingvistike - New in World Linguistics, 17, 170-194 [in Russian].

Shulzhuk, K.F. (1968). Zvertannia v ukrainskykh narodnykh pisniakh [Direct address in the Ukrainian folk songs]. Candidate's thesis. Kyiv [in Ukrainian].

Shynkaruk, V.D. (2002). Katehorii dyktumu i modusu u strukturi rechennia [Categories of dictum and modus in the sentence structure]. Chernivtsi: Ruta [in Ukrainian]. 
Tillman, R., \& Louwerse, M. (2018). Estimating Emotions Through Language Statistics and Embodied Cognition. Journal of Psycholinguistic Research, 47(1), 159-167. https://doi.org/10.1007/s10936-017-9522-y

Vykhovanets, I.R. (1993). Gramatyka ukrainskoi movy. Syntaksys [Grammar of the Ukrainian language. Syntax]. Kyiv: Lybid [in Ukrainian].

Yasakova, N.Y., Kharchenko, S.V., \& Shynkaruk, V.D. (2019). Verbal indicators of linguistic and cultural identity (personal pronouns as the example). Cogito, XI(4), 201-214.

Zaucha, J. (2016). Jednostki apelatywne. W poszukiwaniu wyróżnika. LingVaria, 1(21), 83-98. https://doi.org/10.12797/LV.11.2016.21.08

\section{Sources}

Vynnychenko, V (1999). Opovidannia. Slovo za toboiu, Staline; Chorna Pantera i Bilyi Medvid: Roman [Short Story. You Have the Final Say, Stalin; Black Panther and Polar Bear: Novel]. Kyiv: Naukova dumka [in Ukrainian].

Vilde, I. (2010). Sestry Richynski [The Richynski Sisters]. Kyiv: Zelenyi pes [in Ukrainian].

Holovko, A. (2017). Burian [Weeds]. Kyiv: Vydavnytstvo «Tsentr navchalnoi literatury» [in Ukrainian].

Honchar, O.T. (1987). Tvory [Works] (Vols. 1-7). Kyiv: Dnipro [in Ukrainian].

Dashvar, L. (2011). Byti ye [Byti Ye] (Book 1: Makar). Kharkiv: Knyzhkovyi Klub «Klub simeinoho dozvillia» [in Ukrainian].

Donchenko, O.V. (1987). Shkola nad morem: Povist ta opovidannia [School Above the Sea: Tale and Short Story]. Kyiv: Veselka [in Ukrainian].

Zarudnyi, M. (1979). Hileia [Hylea]. Kyiv: Dnipro [in Ukrainian].

Zemliak, V.S. (1981). Lebedyna zgraia. Zeleni Mlyny [Swan Flock. Green Mills]. Kyiv: Dnipro [in Ukrainian].

Kvitka-Osnovianenko, H. (1978). Tvory $v$ dvokh tomakh [Works in Two Volumes] (Vol. 2). Kyiv: Dnipro [in Ukrainian].

Kulish, P. (1990). Chorna rada [Black Council]. Kyiv: Dnipro [in Ukrainian].

Pidmohylnyi, V. (1989). Misto [City]. Kyiv: Molod [in Ukrainian].

Rozdobudko, I. (2011). Vin: Rankovyi prybyralnyk. Vona: Shosti dveri [He: Morning Cleaner. She: The Sixth Door]. Kyiv: Nora-Druk [in Ukrainian].

Slisarenko, O.A. (1990). Chornyi anhel: Virshi. Novely. Povisti. Roman [Black Angel: Poems. Novellas. Tales. Novel]. Kyiv: Dnipro [in Ukrainian].

Tarasiuk, H.T. (2006). Zhinochi romany: proza [Female Novels: Prose]. Brovary: Vidrodzhennia [in Ukrainian].

Franko, I. (2006). Zakhar Berkut [Zakhar Berkut]. Kyiv: Shkola [in Ukrainian].

\section{АНОТАЦІЯ}

Мета дослідження - обгрунтувати психолінгвістичні параметри категорії спонукальної модальності, що має безпосередній зв'язок із низкою психічних феноменів та з мовцем та адресатом, та описати через механізми та процеси сприйняття, інтерпретації та породження мовлення психолінгвістичну 
модель акту волевиявлення в поєднанні з вивченням закономірностей функціонування мовленнєвої одиниці в певному психолінгвальному просторі та ії інтерпретування адресатом.

Методи дослідження. Для досягнення сформульованої мети як основний використано описовий метод із властивими йому прийомами зовнішньої та внутрішньої інтерпретації, прагматичний метод із залученням методики актомовленнєвого аналізу, щоб визначити складники психолінгвістичної моделі спонукального акту та розмежувати види спонукальних висловлень; метод класифікації - для інвентаризації й систематизації непрямоспонукальних висловлень, контекстуально-інтерпретаційний - для встановлення транспозиції неспонукальних висловлень у спонукальні в мовленнєвій діяльності; інтент-аналіз залучено до вивчення непрямоспонукальних висловлень, що в мовленнєвій ситуації адресат інтерпретує як спонукальні.

Результати. Аналіз нерозривного взаємозв'язку психічних, мисленнєвих i мовних процесів дав змогу визначити психолінгвістичні параметри категорії спонукальної модальності, у якій виразно есплікується план змісту (інтенційні потреби мовця: наказ, побажання, застереження тощо) та план мовної репрезентації. На основі цього підходу витлумачено спонукання $і$ як психолінгвістичне поняття, і як лінгвістичну універсальну категорію, визначено складники лінгвістичної моделі спонукального акту та схарактеризовано їхні основні риси. Підкреслено двоспрямованість акту волевиявлення.

Висновки. Орієнтованість на позитивний результат спонукання передбачає обов'язкове врахування відомих або передбачуваних фронових знань, використання однієї знакової системи кодування і декодування інформації, конвенцій, ситуації мовлення тощо.

Ключові слова: спонукання, мовленнєва діяльність, психолінгвістична модель, мотив, потреба, комунікативна ситуація, вокативне висловлення, спонукальна модальність, спонукальні висловлення.

\section{Шинкарук Василий \& Харченко Светлана. Коммуникативно-функциональный потенциал побудительной модальности в психолингвистическом аспекте}

\section{АННОТАЦИЯ}

Цель исследования - обосновать психолингвистические параметры категории побудительной модальности, которая имеет непосредственную связь с рядом психических феноменов и с говорящим и адресатом, и описать через механизмы и процессы восприятия, интерпретации и порождение речи психолингвистическую модель акта волеизъявления в сочетании с изучением закономерностей функционирования языковой единицы в определенном психолингвальном пространстве и ее интерпретации адресатом.

Методы исследования. Для достижения срормулированной чели в качестве основных методов использованы описательный метод с присущими ему приемами внешней и внутренней интерпретации, прагматический метод с привлечением методики акторечевого анализа, чтобы определить 
составляющие психолингвистической модели побудительного акта и разграничить виды побудительных высказываний; метод классификации - для инвентаризации и систематизации косвеннопобудительных высказываний, контекстуально-интерпретационный - для установления транспозиции непобудительных высказываний в побудительные в речевой деятельности; интент-анализ привлечено к изучению косвеннопобудительных высказываний, в речевой ситуации адресат интерпретирует как побудительные.

Результаты. Анализ неразрывной взаимосвязи психических, мыслительных и языковых прочессов позволил определить психолингвистических параметры категории побудительной модальности, в которой отчетливо эксплицируется план содержания (интенционные потребности говорящего: приказ, пожелания, предостережения и т.п.) и план языковой репрезентации. На основе этого подхода рассмотрено побуждение и как психолингвистическое понятие, и как лингвистическая универсальная категория, определены составляющие лингвистической модели побудительного акта и охарактеризованы их основные черты.

Выводы. Ориентированность на положительный результат побуждения предусматривает обязательный учет известных или предполагаемых фоновых знаний, использование одной знаковой системы кодирования и декодирования информации, конвенций, ситуации речи и тому под.

Ключевые слова: побуждение, речевая деятельность, психолингвистическая модель, мотив, потребность, коммуникативная ситуация, вокативное высказывание, побудительная модальность, побудительные высказывания. 